\title{
"A Good Name Is Better than Wealth" in Proverbs 22:1 vis-à-vis the Related Igbo Maxim "Ezi Afa Ka Ego" (Integrity Surpasses Wealth)
}

\author{
DAMIAN O. ODO, KingSLEY I. UWAEGBUTE AND \\ VIRGINUS U. EZE (UNIVERSITY OF NIGERIA)
}

\begin{abstract}
This article studies Proverbs 22:1 in relation to the Igbo maxim, 'Ezi afa ka ego' (Integrity surpasses wealth). The poet of Proverbs 22:1 claims that integrity surpasses wealth and then admonishes people to embrace virtues and shun vices. It is sad to observe that in the Igbo society of Nigeria, some citizens presently engage in ritual killings, human trafficking, prostitution and other vices in the quest to acquire wealth. Against this backdrop, this essay analysed Proverbs 22:1 visa-vis the Igbo proverb, 'Ezi afa ka ego.' The methodology adopted by the researchers is literary analysis, which is a synchronic approach that studies a biblical text as it appears in its final shape. The researchers employed a random sampling technique to interview seven knowledgeable Igbo people orally to examine the meaning of 'Ezi afa ka ego' in the Igbo context. The study affirmed that modernism has negatively affected the Igbo's cherished value of integrity. This study charges those that engage in iniquity in order to acquire wealth to eschew such practices because a good name surpasses wealth.
\end{abstract}

KEYWORDS: Proverbs 22:1, Good name, Integrity, Ezi afa ka ego, Igbo aphorism

\section{A INTRODUCTION}

Israelite wisdom gave rise to a specific type of literature represented in the Old Testament by Job, Proverbs, Ecclesiastes, and some of the Psalms together with Ben Sira and the Wisdom of Solomon in the non-canonical book called

\footnotetext{
* Submitted: 21/05/2019; peer-reviewed: 29/10/2020; accepted: 12/11/2020. Damian O. Odo, Kingsley I. Uwaegbute and Virginus U. Eze, "A Good Name Is Better than Wealth" in Proverbs 22:1 vis-à-vis the Related Igbo Maxim: "Ezi Afa Ka Ego" (Integrity Surpasses Wealth)," Old Testament Essays 33 no. 3 (2020): 428-444. DOI: https://doi.org/10.17159/2312-3621/2020/v33n3a5.
} 
Apocrypha. ${ }^{1}$ Obiorah confirms that biblical Wisdom Literature includes the book of Job, Proverbs, Ecclesiastes, Wisdom, Sirach and wisdom Psalms (cf. Ps $49 ; 73 ; 112 ; 37$ ), which, more than any other part of the Bible, deal with observable human experiences and teach human beings how to live humanely in this world. ${ }^{2}$ It is quite interesting to note that the book of Proverbs was the first in the class of Wisdom Literature to attain canonical status. The maxim of Proverbs 22:1 and the rest of the sayings in the book of Proverbs are regarded as the oldest literary compositions of the canonical wisdom books that offer an excellent starting point for the consideration of the meaning of wisdom in all its aspect. $^{3}$ The thoughtful demonstration of the poet of Proverbs and his observable practical experiences in the society triggered his surging exhortative aphorism in Proverbs 22:1 that a good name is to be chosen to great wealth and honour better than silver and gold. He gave this reflective maxim to admonish human beings to embrace virtue and live humanely in the society.

This article studies the maxim of Proverbs 22:1 and a related Igbo adage Ezi afa ka ego (Integrity surpasses wealth), employing a literary analysis as its methodology. Literary analysis is a synchronic approach that studies a biblical text as it appears in its final shape. ${ }^{4}$ In addition, this research employed a random sampling technique to conduct an oral of interview seven knowledgeable Igbo people about the meaning of the adage, "A good name is better than money," Ezi afa ka ego, in the Igbo context. The data was presented objectively and critically. The poet of Proverbs 22:1claims that integrity surpasses wealth to admonish human beings to cultivate and embrace virtue and shun vices. It is disappointing to observe that in the present Igbo society of Nigeria, many citizens engage in human rituals, human trafficking, prostitution and such acts in the quest to acquire wealth. Against this backdrop, this essay studied Proverbs 22:1 and a related Igbo proverb to underscore its contextual relevance in the Igbo society. The essay is organized in four segments. The first part is an overview of the book of Proverbs. The second section focuses on the

1 S. Donald, "The Book of Proverbs," The Teachers Commentary (London: SCM Press, 1962), 25; Thomas R. Henn, The Bible as Literature (New York: Oxford University Press; 1970), 162.

2 Mary J. Obiorah, "Wealth and Divine Blessing: A Study of the Theological Correction in Proverbs 10:22 in the Nigerian Context," International Journal of African Catholicism 4/1 (2013), 53, www.saintleo.edu.ng/.../international-journal-ofafrican-catholicism.aspx.

3 Carole R. Fontaine, Wisdom in Proverbs (Kentucky: John Knox Press 1993), 99.

4 Odit H. Steck, Old Testament Exegesis: A Guide to the Methodology (Atlanta: Scholars Press, 1995), 21; Albert N. Mundele, A Handbook on African Approaches to Biblical Interpretation (Limuru, Kenya: Kolbe Press, 2012), 11; Caroline. N. Mbonu, "Biblical Exegetical and Hermeneutical Approaches," in Fundamentals of Research Methodology in the Humanities (ed. Christopher I. Ejizu; Port Harcourt: University of Port Harcourt Press, 2013),107; Mary J. Obiorah, Bibliotheca Divina: A Basic Introduction to the Study of the Bible (Nsukka: University of Nigeria Press, 2015), 90. 
critical interpretation of Proverbs 22:1 in its literary context. The third part discusses the Igbo concept of Ezi afa ka ego, while the fourth part borders on the relevance of Proverbs 22:1 in the context of good name and honour in Igbo society.

\section{B AN OVERVIEW OF THE BOOK OF PROVERBS}

The title of the book of Proverbs in the Masoretic text reads "mislê šalomoh ben-david melek yisrā'el." Ackroyd notes that the book is referred to as the "mislê šalomoh" or simply "mislê." 5 It is difficult to establish, with precision, the date of composition of Proverbs and of most of the Old Testament books. McCreesh writes that the actual date of the composition of Proverbs is uncertain. However, he suggests that it was probably put into writing in the late sixth or early fifth century BCE. ${ }^{6}$ The above submission by McCreesh seems convincing. Since Proverbs was the first of the wisdom books to be written, then it is mostly probable that it was composed in the sixth or fifth century BCE. For Gertz et al, this wisdom book was composed in the fourth or third century BCE. ${ }^{7}$ Of a truth, there is no consensus among Old Testament scholars on the dating of Proverbs. Arising from this complexity, Scholars' views on the dating of Proverbs often vary since the author did not state the date of the book. The book of Proverbs is one of the notable wisdom pieces in Old Testament literature that "stresses the presupposition that wisdom is a language of craft." The book has 31 chapters which are all written in the form of poetry.

Old Testament Proverbs consists of different reflective aphorisms of the sages. Sandmel refers to the book as a collection of collections, ${ }^{9}$ perhaps because it deals with various human issues. The sages who composed these inspiring utterances are, no doubt, the archetype of wisdom. They are endowed human beings who, employing the wealth of their experiences and reflective acumen, articulated series of glittering and pedagogical wise sayings to encourage people to live humanely in the society. The wisdom book of Proverbs is a masterpiece that is richly garbed in didactic aphorism. Murphy notes that the literary composition of Proverbs is written to offer guidance and

5 Peter R. Ackroyd, The History of the Formation of the Old Testament (Oxford: Basil Blackwell 1974), 471.

6 Thomas P. McCreesh, "Proverbs," The New Jerome Biblical Commentary (eds. Raymond E. Brown et al. New Jersey: Geoffrey Chapman/Prentice Hall, 2000), 454.

7 John C. Gertz, Angelika Berlejung, Konrad Schmid, and Markus Witte, $T \& T$ Clark Handbook of the Old Testament: An Introduction to the Literature, Religion and History of the Old Testament (London: T \& T Clark, 2012), 582.

8 Robert Alter, The Art of Biblical Poetry (Edinburgh: T \& T Clark, 2000), 167.

9 Samuel Sandmel, The Hebrew Scriptures: An Introduction to Their Literature and Religious Ideas (New York: Oxford University Press, 1976), 259. 
training in virtue. ${ }^{10}$ This sapiential book does not only describe the way of the wise but it also commends it with great persuasion. ${ }^{11}$ In other words, the book of Proverbs is presented as an appeal which is didactic and directed towards right conduct. A serious study of the book of Proverbs perceives that the book addresses persuasively the issue of life by subtly soliciting that right conduct should be sought for and cultivated. Thus, "Proverbs presents us with the wisdom of the ancient Near East in its Israelite and Jewish form." "2 The sages' reflections in the book of Proverbs are current and valid at all times, which mean "that the sages searched for universal truth; they acknowledged no geographical boundaries where insight into reality was concerned." 13

\section{INTERPRETATION OF PROVERBS 22:1}

Proverbs 22:1 is a distich; it is arranged in two lines. This distich is distinct from the rest of the verses and can stand on its own and thus be interpreted separately. The maxim in the Masoretic Text reads thus:

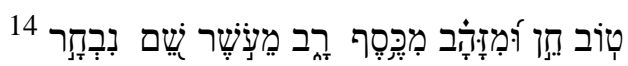

(A good name is more desirable than great riches;

to be esteemed is better than silver or gold) ${ }^{15}$

(Igbo translation of Proverbs 22:1)

Ezi afa ka ego;

inwe nsopulu ka nma kari ola ocha na ola edu

The rendering of this adage is apt and remarkable. The sage clothed his utterance as a glittering literary construction. The English translation of the proverb could be rendered, A good name is to be chosen than many riches and honour is to be chosen to silver and gold. Reading this verse closely and objectively through the lens of Hebrew grammar and syntax undergirds the beauty and acumen exhibited by the poetic sage and writer of this biblical maxim. The Hebrew word מֶy is a combination of two Hebrew words written together as one word. The first word $n$ is a form of the Hebrew preposition min "from," while the second word עָ is is a Hebrew noun which means riches. Taken together, the phrase means "from riches." However, this is not the meaning that the ancient poet intended in the context that the word appears.

${ }^{10}$ Roland E. Murphy, The Tree of Life: An Exploration of Biblical Wisdom Literature (Grand Rapids: Eerdmans Publishing Co, 2002), 16.

${ }^{11}$ Brevard S. Childs, Introduction to the Old Testament as Scripture (Philadelphia: Fortress Press, 1986), 554.

12 Werner H. Schmidt, Old Testament Introduction (New York: T \& T Clark, 1984), 321.

13 James. L. Crenshaw, Old Testament Wisdom (Atlanta: John Knox Press, 1981), 68.

14 The Hebrew text used here is from A. Schenker, Biblia Hebraica Stuttgartensia. (Stuttgart: Deutsche Bibelgesellschaft, 1997), 1303.

15 This translation is from New International Version (Grand Rapids: Zondervan, 2002). 
The construction is laced with a deeper meaning. In fact, the word is used

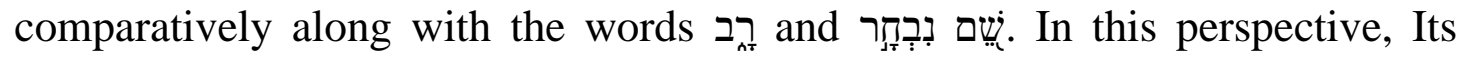
meaning is rendered in the context as, "A good name is to be chosen more than great riches." It is interesting to observe that in this construction, the poet did not alter the noun artistically prefixed the preposition $y$ to the noun statement. On this fascinating Hebrew articulation of thought, Jouon and Muraoka, ${ }^{16}$ and Lambdin ${ }^{17}$ affirm that the adjective is not altered in form to express the comparative. Instead, the preposition " $\min$ " is used before the noun as the basis of comparison. The word fis as it appears in the maxim is one word in Hebrew. However, its translation to English produces four words,

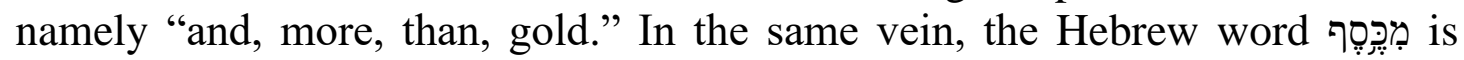
rendered as three English words "better than silver." Taken together, the

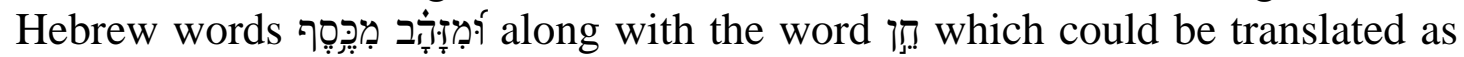
esteem or honour, could be rendered, "to be esteemed is better than silver or gold."

The poet of this captivating ancient sapiential saying explains that attaining a good reputation is to be cherished more than great wealth. "Having a good name" as the poet stated in the maxim entails exhibiting and living a life of virtue which is worthy of emulation. To live this life of virtue is synonymous with living a life of integrity in the present Igbo society that is marked by an inordinate quest to make money. Exploring this biblical verse, Crawford aptly maintains that:

To have good name entails repute. To be well thought of is to have kindly appreciation, good reception from others, to be persona grata (acceptable person). Name is the estimation in which one is held by others during life and after death. ${ }^{18}$

Interpreting the above view by Crawford brings to light the sparkling utterances of the writer in the verse that a person of integrity is preferred in the society to a person with many riches. Crawford claims that having good repute, involving high intellectual and moral character, is a more precious possession than material wealth. ${ }^{19}$ The author of Qohelet expresses this theme slightly in the first line of 7:1, thus: "A good name is better than precious ointment." Striving for and acquiring a good name in the society is training in virtue which is a precious and priceless attainment that should be preferred to wealth. In this

16 Paul S. Jouon and Takamitsu J. Muraoka, Subsidia biblica: A Grammar of Biblical Hebrew (Roma: Editrice Pontificio Isituto Biblico, 1993), 522-523.

17 Thomas Lambdin, Introduction to Biblical Hebrew (London: Darton, Longman and Todd,1973), 23.

18 Toy H. Crawford, Critical and Exegetical Commentary on the Book of Proverbs (Edinburgh: T \& T Clark George Street, 1959), 413.

${ }_{19}$ Crawford, Critical and Exegetical Commentary on the Book of Proverbs, 413. 
regard, Delitzsch writes that a man of integrity is antithetic to a man that hungers for wealth and pursues it in a questionable way, ${ }^{20}$ as is being witnessed in the present Igbo society. Further, to "make oneself a name is equivalent to build a monument in honour of oneself." 21 Delitzsch's interpretation is valid judging from the standpoint of the second poetic line of Proverbs 22:1 which affirms that to be esteemed is better than silver or gold. What this entails arguably is that a person who acquired wealth in a dishonest manner is no longer a person of integrity which the poet of Proverbs 22:1 reveals should be chosen rather than silver and gold. The idea that a good name is better than wealth expressed in the first poetic line is heightened in the second line, which says that to be "esteemed" is to be chosen above silver and gold. This is a perfect example of "synonymous parallelism" 22 whereby the idea raised in the first line is repeated in the second poetic line employing slightly different words.

It should be noted that the poet of this text does not condemn, in any way, wealth. Wealth acquired in a just way is a blessing from God and it is highly commendable especially to use it to assist the poor and the needy in the society. Acquiring wealth in a rightful way is not bad. Without doubt, wealth attained in such probity is not only good but also admirable and hence, to be encouraged. However, what the poet of Proverbs 22:1 discourages is placing wealth above reputation. It is against this backdrop that the poet declares that, "A good name is to be chosen to great wealth." Arguably, a person of integrity immortalises his/her name while alive and leaves an indelible mark on the sands of time. In fact, "good reputation and public approval are a firmer basis for a good life in society than wealth." ${ }^{23}$ In other words, a good name lasts forever.

Constable also writes that, "a good name is an asset whose currency is unaffected by the boom or bust of the material world." 24 The poet of Proverbs 22:1 perhaps, had witnessed many of his contemporaries lusting for wealth and acquiring it in dishonest manners. Therefore, to dissuade people from inordinate quest for wealth, he polished this reflective and inspiring artistic

20 Z. Franz Delitzsch, Biblical Commentary on the Proverbs of Solomon (Grand Rapids: Eerdmans, 1980), 83.

21 Delitzsch, Biblical Commentary on the Proverbs of Solomon, 83.

22 Malachy I. Okwueze, The Old Testament as History, Religion and Literature (Onitsha: African First Publishers, 2013), 247; Gareth Crossley, The Old Testament Explained and Applied (Darlington: Evangelical Press, 2002), 470; Damian O. Odo, "Dialectics on Theodicy in Job 9:1-24 in the Context of Christians in Enugu State" (PhD dissertation: University of Nigeria Nsukka, 2019), 100.

${ }^{23}$ Lucas, Ernest C., Proverbs (Grand Rapids: William B. Eerdmans, 2015), 149.

24 Thomas Constable, "Commentary on Proverbs 22:1," The Expository Notes of Dr. Thomas Constable, https://www.studylight.org/commentaries/dcc/proverbs-22.html. 
aphorism that a good name and honour are to be chosen above great wealth. ${ }^{25}$ Tate agrees that integrity is more precious and valuable in the society than many riches. ${ }^{26}$ In Gill's view, it is not any name that is more eligible than riches but a good name, which is more preferable to many riches ${ }^{27}$ because wealth, like other earthly materials, passes away but a good name endures forever. The shining maxim of our text ascribes prominence to good name over great wealth. For Wright, the wealthy are given wealth to help the poor which means that the rich lighten their load by giving away some of their possessions to the needy. Obviously, only rich people who are wise extend their hands to the poor and by so doing make themselves fame with their wealth. Hence, a good name is more excellent than money and honour is better than heaps of silver. $^{28}$

Contributing to this theme, Ackroyd explains that it was the hope of every Israelite that he would be remembered for the good which he had done and that his name or his good reputation would endure permanently. ${ }^{29}$ Ackroyd's view shows that after death, the only legacy that outlasts death is a good name and reputation which the person had inscribed permanently on the sands of time. In other words, no rich person is remembered after death for his/her great wealth but for the charitable and positive impact that he or she made with the wealth while on earth. The poet of Proverbs 22:1 perhaps knew that only a good name and reputation last forever hence prioritised it over great wealth. Habtu writes that a good name, like wisdom, is more desirable than great wealth; to be esteemed is better than silver or gold. He explicates that having a good name is one of wisdom's highest prizes. He maintains that this is in line with the African worldview that a good name is required for acceptance by the community in order to be able to have a positive impact on others. ${ }^{30}$

${ }^{25}$ Bruce C. Birch, Walter Brueggemann, Terence E. Fretheim, and David L. Petersen, A Theological Introduction to the Old Testament (2nd ed.; Nashville: Abingdon, 2005), 383.

${ }^{26}$ Marvin E. Tate, "Proverbs," The Broadman Bible Commentary (ed. Clifton J. Allen; Nashville: Broadman Press, 1971), 69.

27 John Gill, "Commentary on Proverbs 22:1," The New John Gill Exposition of the Entire Bible, https://www.biblestudytools.com/commentaries/gills-exposition-of-thebible.

28 J. Robert Wright, Ancient Christian Commentary on Scripture. Old Testament: Proverbs, Ecclesiastes, Song of Solomon (Downers Grove: Inter Varsity Press, 2005), 130.

29 Ackroyd, The History of the Formation of the Old Testament, 471.

30 Tewoldemedhin Habtu, "Proverbs," in African Bible Commentary (ed. Tokunboh Adeyamo; Nairobi: Zondervan, 2006), 803. 


\section{IGBO CONCEPT OF EZI AFA KA EGO (REPUTATION/INTEGRITY SURPASSES WEALTH)}

This section examines the Igbo concept of Ezi afa ka ego (Reputation/integrity surpasses wealth). The idea of Ezi afa ka ego in Igbo philosophy is highly valued and acknowledged. Integrity or a good name is one of the values the Igbo people highly esteem. Wealth acquisition is a good attainment in life. However, this accomplishment is only praised or evaluated in the light of the probity lens. Igbo people understand that a good name or reputation surpasses great wealth. Consequently, they articulate this shinning aphorism that the poet of Proverbs 22:1 celebrates as a good name is to be chosen above great wealth and to be esteemed above silver and gold that the Oxford Advanced Learners Dictionary of Current English defines integrity as the "quality of being honest and having strong moral principles." 31

In Igbo worldview, names speak volumes about a person. Hence, various expressions in Igbo explain the reputation and integrity of a person. A person of high integrity is esteemed and regarded greatly in Igbo society. Igbo people strive to have a stainless character in order to portray their family virtues. Explaining this notion of good reputation in the context of Igbo society, Ndukaihe states that even his own name Ndukaihe (Life is supreme) and Eziafa ka ego attest to this Igbo philosophy. ${ }^{32}$ Ubahakwe also notes that:

Interestingly, African people believe that a person's names are not simple labels used for mere identification purposes or baggage tags. On the contrary, an indigenous African name on the whole personifies the individual; it tells some story about the parents or family of the bearer and in a more general sense points to the values of the society into which the individual is born. ${ }^{33}$

A critical interpretation of the above citation brings to the fore a resonance with the statement in Proverbs 22:1. Clothing oneself with a good name, arguably, surpasses great wealth. Posner affirms that the value of integrity is very much associated with the virtue of honesty and a sense of justice. These virtues play vital roles in the assignment of responsibility and any elevation to public positions. Posner observes that in the traditional Igbo society, to achieve a high status or to be communally accorded with highly esteemed titles like $O z o$ (a traditional name given to a king in some Igbo communities), one must be known in the community as a person of probity

31 Albert S. Hornby, Oxford Advanced Learners Dictionary of Current English (7th edition; Oxford: Oxford University Press, 2005), 776.

32 Vernantius E. Ndukaihe, Achievement as Value in the Igbo/African Identity: The Ethics (Hamburg: Lit Verlag, 2006), 225.

33 E. Ubahakwe, "Culture Content of Igbo Personal Names," in Igbo Language and Culture (eds. F.C. Ogbalu and E.N. Emenanjo; Ibadan: Oxford University Press, 1978), 27. 
who values personal dignity or honour more than material gains. ${ }^{34}$ This perhaps explains the formulation of the Igbo philosophical and didactic aphorism, Ezi afa ka ego (Integrity surpasses great wealth) in order to discourage the illegal acquisition of wealth.

Scholars such as Eboh $^{35}$ and Okwueze ${ }^{36}$ maintain that traditional Igbo society had firm moral structures which informed and ensured conformity to the accepted norms. Put differently, the traditional Igbo society placed priority on integrity and a good name over the ill acquisition of wealth. ${ }^{37}$ Kanu avers that these cherished cultural values help in nurturing good and acceptable human relationship in the cultural web of the Igbo people which discourage unjustifiable means of acquiring money. ${ }^{38}$ It is unfortunate that in Igbo society today, the wave of civilisation and modernity has negatively affected the traditional Igbo maxim of Ezi afa ka ego. Thus, Onunwa ${ }^{39}$ laments bitterly that a new social order is emerging in Igbo society as a response to the new contact with the powerful external change agents.

Similarly, one of the interview respondents, Ifeanyi, condemned this development, and notes that in the contemporary Igbo society, many believe more in wealth than in a good name. He maintained that there is a great misplacement of values, particularly regarding wealth, and this perhaps explains why some Igbo people deviate from cherished virtues such as good reputation to engage in an inordinate pursuit of wealth. ${ }^{40}$ It is on this basis that one could understand the misguided conception that a true confirmatory test that an Igbo person is truly dead is when money touches the corpse and it does not respond. However, caution should be applied with such a saying since it has no place in Igbo cultural life, as most of the Igbo proverbs and piety sayings show. A critical analysis of Ifeanyi's view seems to underscore a hunger for wealth as a compelling factor that drive people into vices. The Igbo

34 Eric A. Posner, Law and Social Norms (Cambridge: Harvard University Press, 2006), 34.

35 Ben O. Eboh, Living Beyond Materialism (Enugu: SNAAP Press, 1994), 13.

36 Malachy I. Okwueze, "Exorcism and Healing in Igbo Traditional Religion: Old Testament and Pentecostalism," Religion and Societal Development (ed. Malachy I. Okwueze; Lagos: Merit International Publications, 2004), 241.

37 See E. Ifesieh, Religion at the Grassroots: Studies in Igbo Religion (Enugu: Fourth Dimension Publishers, 1989), 30; C. Ochiagha, Value Re-Orientation Programme for Youths: An Alternative Approach (Onitsha: Spiritan Publications, 1996), 45.

38 Rex C. Kanu, "African Traditional Morality and Nation Building," Religion and Societal Development, (ed. Malachy I. Okwueze; Lagos: Merit International Publications, 2004), 87.

39 Udobata Onunwa, Studies in Igbo Traditional Religion (Obosi: Pacific Publishers, 1990), 31.

${ }^{40}$ Ifeanyi, Interview, 23 May 2017. 
understanding of Ezi afa ka ego entails that one should, even in a very tasking or challenging situation, maintain one's integrity. In his contribution, another respondent, Sunday, explained that an Igbo person whose morality or moral life is still intact can forfeit an admirable gift or wealth if such will jeopardise his reputation. ${ }^{41}$ Sunday's statement commends an Igbo person who values his integrity over wealth.

Furthermore, Ndukaihe aptly notes that in Igbo society:

A person of integrity is ready to forfeit a high fortune, a rare gift, a high position in the private or public sector if he senses that the acceptance of such gift or honour would bring degradation to his person or reduce his honour and integrity. He would prefer to remain poor rather than to accommodate a situation that might impinge on his freedom and reputation and prestige. ${ }^{42}$

The ability to say 'no' to vices gives one access to a good name. The Igbo people's understanding of a good name or integrity correlates with the Jewish perception of reputation. For example, through Joseph's resistance of the sexual advances of Potiphar's wife, the author of the Joseph narrative in the Old Testament underscores the view that a good name endures forever. Attaining this feat means that one has succeeded in immortalising one's name while alive and even after one's death. However, those who killed fellow human beings to become rich have stained their reputation. Wealth, especially one acquired in an unjustifiable manner, is vanity. This point is well expressed by Qohelet. The sage of Qohelet understands the brevity of human struggle under the sun as vanity, without an enduring memorial which time and death cannot touch, ${ }^{43}$ that is, a good name.

The Daily Post of 1st January 2016 reported that a dead body was discovered in the foundation one of the buildings along the Enugu PortHarcourt Express Road at Ugwuaji Area of the State. Some residents of the area believed that the building was to be a proposed place of worship belonging to a 'ritualist' who disguised himself as a man of God. ${ }^{44}$ On 26 July 2016, about six months after the above report, the same newspaper reported a similar crime by a pastor (denomination not mentioned) who was nabbed by the police for the ritual killing of his wife. ${ }^{45}$ In addition, the Vanguard News reported the

41 Sunday, Interview, 4 July 2018.

${ }^{42}$ Ndukaihe, Achievement as Value in the Igbo/African Identity, 274.

43 Eric Ortlund, "Deconstruction in Qohelet: A Response to Mark Sneed," Journal for the Study of the Old Testament 40/2 (2015): 239-256. Doi: 117710/0309089215611547.

44 E. Uzodinma, "Dead Bodies Discovered in Foundation of Enugu Church Building," $\quad$ www.dailypostng/2016/01/25/breaking-deadbodies-discovered-infoundation.

45 D. Ogbeche, "Pastor Who Allegedly Used Wife for Rituals Arrested in Edo." 
case of one Mr. Ifeanyi Maxwell, a second year student of the University of Port Hart-court, Rivers State, Nigeria, who was nabbed by the police for murdering eight-year old Miss Chikamso Victory for ritual purposes. ${ }^{46}$ These acts are barbaric and evil. Decrying this anomaly, both Mr. Onah, a traditional ruler, and Mr. Fidelis, a traditional prime minister and retired primary school teacher, explained that in the past, Igbo people preferred to remain poor and retain their integrity than to soil their hands in order to acquire wealth. ${ }^{47}$ Similarly, another interviewee, Charity pointed out that Ezi afa ka ego entails that the name of the family should be protected and not be soiled by the quest for money. This is because according to her, one's family name or integrity surpasses wealth. She lamented that at present, the Igbo society seems to have been overtaken by the credo of modernism as the emphasis is now on money and not value. ${ }^{48}$

On the other hand, many Igbo sons and daughters like Professor Chinua Achebe, Nnamdi Benjamin Azikiwe, and Professor Dora Akunyili fought greatly for integrity in their lifetime. Another respondent, Ezekiel, recalled that:

It is quite interesting to note that Dora Akunyili fought gallantly as she refused to be bribed by the drug barons who wanted her to soil her integrity and hence become a very wealthy woman. Our grandfathers were equally people of integrity. For them, there was no amount of wealth that equalled good name. This explains the reason why not long ago, before parents could allow someone to marry their daughter, a thorough inquiry was to be made so as to establish that the family of the suitor was a family with good name. Wealth was secondary. In contrast, nowadays, wealth has become primary and a good name secondary. ${ }^{49}$

The negative effect of this new development is that a heavy blow has been unleashed on the Igbo's cherished maxim, Ezi afa ka ego. Otherwise, how can one explain that some of the Igbo drug dealers at Onitsha Head Bridge Market in Anambra State, Nigeria, engage in production and selling of fake drugs in order to make excess money ${ }^{50}$ The news is also awash with much talk about Chukwudi Dume-ne Onwuamadike popularly known as Evans who led the gangs that carried out a bloody robbery operation in Nsukka in 2009, killing

${ }^{46}$ D. Iheamnachor, "Deadly Neighbour: 23-yr-old Defiles, Murders, Mutilates 8-yrold

Read more at: https://www.vanguardngr.com/2017/08/deadly-neighbour-23-yr-olddefiles-murders-mutilate-8-yr-old-girl/.

47 This thought was expressed by both Cletus and Fidelis in interview on 5 July 2018.

48 Charity, Interview, 7 June 2018.

49 Ezekiel, Interview, 24 June 2017.

50 The New Humanitarian, "Officials Boost Fight against Counterfeit Drugs," 2007, https://www.thenewhumanitarian.org/fr. 
some police officers including a Divisional Police Officer. ${ }^{51}$ Evans did not care about his reputation as he was bent on becoming rich through crooked means. This inordinate inclination for material wealth rather than good name/integrity has led to an increase in social vices such as human trafficking, ritual killings of human beings, prostitution and other evil acts among the Igbo today. Some zealous and desperate prominent women that want to become rich quickly often lure unsuspecting young women from poor economic background into prostitution. ${ }^{52}$ It is an abuse and violation of fundamental human rights to use trickery and force to lure fellow human beings into prostitution in order to acquire wealth. The "issue of human rights violations wherever it occurs, paints a picture of man's inhumanity to man (sic)." 53

It is observed that the expression "integrity surpasses wealth" (Ezi afa ka ego) has parallel sayings in other Nigerian languages. For example, James explained that "Ezi afa ka ego" is captured in Hausa language as, "suna Mai kyau ya fi arziki." He maintained that no amount of money is comparable to having a good name or that the good that is associated with one's name is better than the little or much money one has. ${ }^{54}$ In addition, Ademilokun confirms that Yoruba language has a similar maxim, "Oruko gidi san ju wura ati fadaka lo" (Integrity surpasses great wealth), which is used to commend persons of integrity. ${ }^{55}$ Urhobo people also have a similar saying. Oyiborhoro asserts that in Urhobo language, the saying that integrity surpasses wealth is

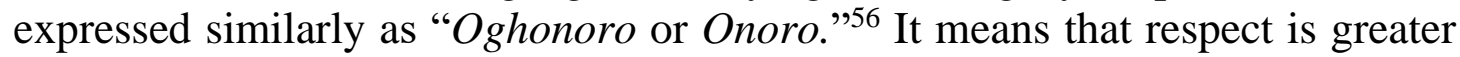
than gold or riches.

${ }^{51}$ For details, see E. Nnadozie, W. Abdulah and I. Okoli, "I Took to Crime After My Father Disowned Me," Vanguard 14 June 2017, https://allafrica.com/stories/201706140562.html.

${ }^{52}$ Kayode A. Adebayo, "The Role of Parents in Combating Human Trafficking and Child Labour," in The Rape of the Innocents Involving an African Initiative against Human Trafficking-proceedings of the First Pan-African Conference on Human Trafficking, Abuja, Nigeria, 19th-23rd February, 2001 (ed. Tunde Fagbohungbe Abuja: WOTCLEF Publication, 2001), 187-193.

53 Malachy I. Okwueze and Rex C. Kanu, Religion and the Healing of Human Rights Violations (Enugu: Don Simons Publications, 2003), 5.

${ }^{54}$ James, Personal Communication, 30/8/2017

${ }^{55}$ Mohammed A. Ademilokun, articulates that Integrity surpasses great wealth in Yoruba cosmology. This is elaborated in his work "Yoruba proverbs and the anticorruption crusade in Nigeria," Inkanyiso: Journal of Humanities and Social Sciences 6/1 (2014): 41-48. See https://www.ajol.info/index.php/ijhss/article/view/105746.

56 A. Oyiborhoro explains that respect or good manner is treasured highly in Urhobo than many riches or gold. This is captured in his article "Urhobo Names and their Meanings," www.waado.org/names/urhonames-oyibo.htm. 
440 Odo et al., "Good Name,” OTE 33/3 (2020): 428-444

\begin{tabular}{|c|c|c|c|c|c|c|c|c|}
\hline $\mathrm{S} / \mathrm{N}$ & $\begin{array}{l}\text { Name of } \\
\text { interviewee }\end{array}$ & Sex & Age & Occupation & $\begin{array}{l}\text { Place of } \\
\text { Residence }\end{array}$ & $\begin{array}{l}\text { Mode of } \\
\text { interview }\end{array}$ & $\begin{array}{l}\text { Date of } \\
\text { interview }\end{array}$ & $\begin{array}{l}\text { Name of } \\
\text { interviewer }\end{array}$ \\
\hline 1 & James & $\mathrm{M}$ & 47 & Clergy & Okigwe & Messenger chant & $30 / 8 / 20218$ & $\begin{array}{l}\text { Odo } \\
\text { Damian }\end{array}$ \\
\hline 2 & Ngozie & $\mathrm{F}$ & 43 & Civil servant & Nsukka & $\begin{array}{l}\text { Face to Face } \\
\text { interview }\end{array}$ & $4 / 6 / 2018$ & $\begin{array}{l}\text { Odo } \\
\text { Damian }\end{array}$ \\
\hline 3 & Ifeanyi & $\mathrm{M}$ & 53 & Civil servant & $\begin{array}{l}\text { Nsukka/Enugu } \\
\text { State }\end{array}$ & $\begin{array}{l}\text { Face to face } \\
\text { interview }\end{array}$ & $5 / 23 / 2017$ & $\begin{array}{l}\text { Uwaegbute } \\
\text { Kingsley }\end{array}$ \\
\hline 4 & Fidelis & $\mathrm{M}$ & 65 & $\begin{array}{l}\text { Traditional } \\
\text { Prime } \\
\text { minister/Retired } \\
\text { civil servant }\end{array}$ & $\begin{array}{l}\text { Orba/ Enugu } \\
\text { State }\end{array}$ & $\begin{array}{l}\text { Face to Face } \\
\text { interview }\end{array}$ & $5 / 7 / 2018$ & $\begin{array}{l}\text { Eze } \\
\text { Virginus }\end{array}$ \\
\hline 5 & Charity & $\mathrm{F}$ & 38 & $\begin{array}{l}\text { Primary School } \\
\text { teacher }\end{array}$ & Agbani & $\begin{array}{l}\text { Face to Face } \\
\text { interview }\end{array}$ & $7 / 6 / 2018$ & $\begin{array}{l}\text { Eze } \\
\text { Virginus }\end{array}$ \\
\hline 6 & Ezekiel & $\mathrm{M}$ & 60 & Trader & $\begin{array}{l}\text { Awka/ } \\
\text { Anambra } \\
\text { State }\end{array}$ & Messenger chant & $24 / 6 / 2017$ & $\begin{array}{l}\text { Uwaegbute } \\
\text { Kingsley }\end{array}$ \\
\hline 7 & Onah & $\mathrm{M}$ & 63 & $\begin{array}{l}\text { Traditional } \\
\text { Ruler }\end{array}$ & $\begin{array}{l}\text { Orba/ Enugu } \\
\text { State }\end{array}$ & $\begin{array}{l}\text { Face to face } \\
\text { interview }\end{array}$ & $8 / 7 / 2018$ & $\begin{array}{l}\text { Odo } \\
\text { Damian }\end{array}$ \\
\hline
\end{tabular}

Table: Socio-demographic Information on Interviewees

\section{E CONTEXTUAL RELEVANCE OF PROVERBS 22:1 AS REGARDS GOOD NAME AND REPUTATION IN IGBO SOCIETY}

Having discussed some social ills relating to the disregard for a good name and reputation in contemporary Igbo society, it becomes pertinent to discuss the relevance of our interpretation of Proverbs 22:1 to tackling these anomalies.

First is the condemnation of excessive desire for wealth at the expense of a good name and reputation. In the preceding subsection, we saw that hunger for wealth and riches were the driving force behind the desire for wealth and riches among some Igbo people today. Our reading of the Proverbs 22:1 calls for the consciousness that a good name and reputation should be the watchword for the Igbo who desire riches. Hence, a person's image and integrity are an important part of who the person is. The Igbo people strongly believe this saying, although the belief has been threatened by modern trends. Thus, Proverbs 22:1 is a call to revert to this belief and esteemed practice in the pursuit of wealth and better life.

Second, the get-rich-at-all-cost syndrome, seen today among some Igbo people, stems from greed and lack of contentment. Greed and lack of contentment partly lead to the disregard for a good name and reputation at the expense of getting rich at all cost. The text of Proverbs 22:1, with its emphasis on a good name being better than riches serves to curtail greed and the inordinate quest for wealth among some Igbo people today. If Igbo people as 
agree with Proverbs 22:1 that a good name is paramount, then, the greed that leads them to engage in horrendous acts in the bid to make money will be curbed, and they will enjoy contentment and satisfaction.

Third, our reading of Proverbs 22:1 has certain implications for the reduction of crime and criminality spurred by the love of wealth in the present Igbo society. While discussing the Igbo concept of Ezi afa ka ego, we brought to the attention of the readers some of the evil acts perpetrated by some Igbo people in the bid to acquire wealth. In fact, greed has led to a high crime rate in the Igbo society, including kidnapping, prostitution, the production and selling of fake drugs, armed robbery and other evils. In this regard, our reading of Proverbs 22:1 with its emphasis on the good name, if imbibed by the people, will lead to a reduction in crime and criminality in Igbo society.

Fourth, the poetic maxim of Proverbs 22:1 has a hermeneutical implication for family reputation among the Igbo people who also have a high regard for family integrity. In the Igbo context, a good family name is important to the image of the people that come from such a family. On the contrary, a bad family name brings scorn to the image of the community at large. Hence, when one engages in a crime in a bid to make money, it is believed that the image of the family as well as that of the community is soiled. Thus, if imbibed by Igbo people, the reading of Proverbs 22:1 in the context of a good name being more precious and valuable than riches will lead to a high regard for family image and reputation which will also bolster community image and reputation.

\section{F CONCLUSION}

The poetic articulation of the sage in Proverbs 22:1 is, no doubt, a locus classicus of the Old Testament Sapiential Corpus. This illuminating maxim emanating from the ancient Jewish poet stresses that a good name is more valuable in the society than great wealth. A critical survey of the aphorism of Proverbs 22:1 has brought to the fore that people of integrity should be accorded more respect and celebrated in the land than the men of great wealth without reputation. A juxtaposed study of the text within the context of Igbo society has shown that some Igbo citizens indulged in ritual killings, prostitution, human trafficking, armed robbery, the production and selling of fake drugs and other crimes in order to acquire wealth. The study highly condemns such acts and encourages those that engage in these anomalies to desist from them because a good name is more precious than wealth.

\section{G BIBLIOGRAPHY}

Ackroyd, Peter R. The History of the Formation of the Old Testament. Oxford: Basil Black Well, 1974.

Adebayo, Kayode A. "The Role of Parents in Combating Human Trafficking and Child Labour." Pages 187-193 in The Rape of Innocents Involving an African 
Initiative against Human Trafficking-Proceedings of the First Pan-African Conference on Human Trafficking, Abuja, Nigeria, 19th-23rd February, 2001.

Edited by Tunde Fagbohungbe. Abuja: WOTCLEF Publication 2001.

Ademilokun, A. Mohammed. "Yoruba proverbs and the anti-corruption crusade in

Nigeria", Inkanyiso: Journal of Humanities and Social Sciences 6/1 (2014):

41-48. See https://www.ajol.info/index.php/ijhss/article/view/105746

Alter, Robert. The Art of Biblical Poetry. Edinburgh: T \& T Clark, 2000.

Birch, Bruce C., Walter Brueggemann, Terence E. Fretheim, and David L. Petersen. A

Theological Introduction to the Old Testament. 2nd edition. Nashville: Abingdon, 2005.

Brueggemann, W. A. et al. Israelite Wisdom. New York: Scholars Press, 1979.

Childs, Brevard S. Introduction to the Old Testament as Scripture. Philadelphia:

Fortress Press, 1986.

Constable, Thomas. "Commentary on Proverbs 22:1." The Expository Notes of Dr.

Thomas Constable. Cited 16 November $2020 . \quad$ Online:

https://www.studylight.org/commentaries/dcc/proverbs-22.html. 2012.

Crawford, Howell T. Critical and Exegetical Commentary on the Book of Proverbs. Edinburgh: T \& T Clark, 1959.

Crenshaw, James L. Old Testament Wisdom. Atlanta: John Knox Press, 1981.

Crossley, Gareth. The Old Testament Explained and Applied. Darlington, UK: Evangelical Press, 2002.

Delitzsch, Franz Z. Biblical Commentary on the Proverbs of Solomon. Grand Rapids: Eerdmans, 1980.

Donald S. "The Book of Proverbs." The Teachers' Bible Commentary. London: SCM Press, 1962.

Eboh, Ben O. Living Beyond Materialism. Enugu: SNAAP Press, 1994.

Fontaine, Carole. Wisdom in Proverbs. Louisville, KY: John Knox Press, 1993.

Gill, John. "Commentary on Proverbs 22:1." The New John Gill Exposition of the Entire Bible, 1999. Cited 16 November 2020. Online: https://www.studylight.org/commentary/proverbs/22-1.html.

Gertz, John C., Angelika Berlejung, Konrad Schmid and Markus Witte. $T$ \& $T$ Clark Handbook of the Old Testament: An Introduction to the Literature, Religion and History of the Old Testament. London: T \& T Clark, 2012.

Habtu, Tewoldemedhin. "Proverbs." Pages 773-812, African Bible Commentary. Edited by Tokunboh Adeyemo/Nairobi: Zondervan 2006.

Hornby, S. Oxford Advanced Learners Dictionary of Current English. 7th edition. Oxford: Oxford University, 2005.

Ifesieh, E. Religion at the Grassroots: Studies in Igbo Religion. Enugu: Fourth Dimension Publishers, 1989.

Iheamnachor, D. "Deadly Neighbour: 23-yr-old Defiles, Murders, Mutilates 8-yr-old Girl.” https://www.vanguardngr.com/2017/08/deadly-neighbour-23-yr-olddefiles-murders-mutilate-8-yr-old-girl/.

Jouon, Paul S. and J. Muraoka. Subsidia Biblica: A Grammar of Biblical Hebrew. Roma: Editrice Pontificio Isituto Biblico, 1993.

Kanu, Rex C. "African Traditional Morality and Nation Building." Pages 79-93 in Religion and Societal Development. Edited by M. I. Okwueze. Lagos: Merit International Publications, 2004. 
Lambdin, Thomas. Introduction to Biblical Hebrew. London: Darton, Longman and Todd, 1973.

Lucas, Eric C. Proverbs. Grand Rapids: William B. Eerdmans, 2015.

Mbonu, Caroline N. "Biblical Exegetical and Hermeneutical Approaches." Pages in Fundamentals of Research Methodology in the Humanities. Edited by Christopher I. Ejizu. Port Harcourt: University of Port Harcourt Press, 2013.

McCreesh, Thomas P. "Proverbs." Pages 453-461 in The New Jerome Biblical Commentary. Edited by Raymond et al. Englewood Cliffs: Geoffrey Chapman/Prentice Hall, 2000.

Mundele, Ngengi A. A Handbook on African Approaches to Biblical Interpretation. Kenya: Kolbe Press, 2012.

Murphy, R. The Tree of Life: An Exploration of Biblical Wisdom Literature. Grand Rapids: Eerdmans, 2002.

Ndukaihe, Vernantius E. Achievement as Value in the Igbo/African Identity: The Ethics. Hamburg: Lit Verlag, 2006.

Nnadozie, E. W. and I. Okoli. "I Took to Crime after My Father Disowned Me." Vanguard 14 June 2017. Cited 23 June 2018. Online: https://allafrica.com/stories/201706140562.html.

New International Version. Grand Rapids: Zondervan, 2002.

Obiorah, Mary J. "Wealth and Divine Blessing: A Study of the Theological Correction in Proverbs 10:22 in the Nigerian Context." International Journal of African Catholicism 4/1 (2013). Cited 11 June 2019. Online: www.saintleo.edu/.../international-journal-of-african-catholicism.aspx.

Obiorah, Mary J. Bibliotheca Divina: A Basic Introduction to the Study of the Bible. Nsukka: University of Nigeria Press, 2015.

Ochiagha, C. Value Re-orientation Programme for Youths: An Alternative Approach. Onitsha: Spiritan Publications, 1996.

Odo, Damian O. "Dialectics on Theodicy in Job 9:1-24 in the Context of Christians in Enugu State." Ph.D. dissertation: University of Nigeria Nsukka, 2019.

Ogbeche, D. "Pastor Who Allegedly Used Wife for Rituals Arrested in Edo." Cited 4 May 2017. Online: $\quad$ http://dailypost.ng/2016/08/12/pastor-allegedly-usedwife-rituals-arrested-.

Okwueze, Malachy I. "Exorcism and Healing in Igbo Traditional Religion. Old Testament and Pentecostalism." Pages 9-27 in Religion and Societal Development. Edited by M. I. Okwueze. Lagos: Merit International Publications, 2004.

Okwueze, Malachy I. The Old Testament as History, Religion and Literature. Onitsha: African First Publishers, 2013.

Okwueze, Malachy I. and Rex Chika Kanu. Religion and the Healing of Human Rights Violations. Enugu: Don Simons Publications, 2003.

Onunwa, Udobata R. Studies in Igbo Traditional Religion. Obosi: Pacific Publishers, 1990.

Ortlund, Eric. "Deconstruction in Qohelet: A Response to Mark Sneed." Journal for the Study of the Old Testament 40/2 (2015): 239-256.

Oyiborhoro, A. "Urhobo Names and Their Meanings." Cited 8 August 2017. Online: www.waado.org/names/urhonames-oyibo.htm.

Posner, E. A. Law and Social Norms. Cambridge: Harvard University Press, 2006. 
444 Odo et al., “Good Name,” OTE 33/3 (2020): 428-444

Rankin, O.S. Israel's Wisdom Literature: Its Bearing on Theology and History of Religion. London: SCM Press, 1962.

Rowley, H.H. Peak's Commentary on the Bible. Lagos: Thomas Nelson and Sons Ltd., 1976.

Sandmel, Samuel. The Hebrew Scriptures: An Introduction to Their Literature and Religious Ideas. New York: Oxford University Press, 1976.

Schenker, A. Biblia Hebraica Stuttgartensia. Stuttgart: Deutsche Bibelgesellschaft, 1997.

Steck, O.H. Old Testament Exegesis: A Guide to the Methodology. Atlanta: Scholars Press, 1995.

Tate, M.E. "Proverbs." The Broadman Bible Commentary. Edited by J.A. Clifton. Nashville: Broadman Press, 1971.

The New Humanitarian. "Officials Boost Fight against Counterfeit Drugs." Cited 16 May 2020. Online: https://www.thenewhumanitarian.org/fr .

Ubahakwe, E. "Culture Content of Igbo Language Personal Names." Igbo Language and Culture. Edited by F.C. Ogbalu and E.N. Emenanjo. Ibadan: Oxford University Press, 1982.

Uzodinma, E. "Dead Bodies Discovered in Foundation of Enugu Church Building." Online: www.dailypostng/2016/01/25/breaking-deadbodies-discovered-infoundation $4 / 6 / 2018$.

Wright, Robert J. Ancient Christian Commentary on Scripture; Old Testament: Proverbs, Ecclesiastes, Song of Solomon. Downers Grove: InterVarsity Press, 2005.

Damian Onyemaechi Odo (Ph.D), Department of Religion and Cultural Studies, University of Nigeria, Nsukka, E-mail:damian.odo@unn.edu.ng. Orcid: https://orcid.org/0000-0002-9345-0961.

Kingsley Ikechukwu Uwaegbute (Ph.D), Department of Religion and Cultural Studies, University of Nigeria, Nsukka, E-mail: kingsley.uwaegbute@unn.edu.ng. Orcid:_https://orcid.org/0000-0002-96970444.

Virginus Uchenna Eze. Department of Religion and Cultural Studies, University of Nigeria, Nsukka. E-mail: virginus.eze@unn.edu.ng. Orcid: https://orcid.org/0000-0002-8523-5321. 